\title{
First serological detection of Borrelia spp. in dogs in western Cuba
}

\author{
Primeira detecção sorológica de Borrelia spp. em cães na região oeste de Cuba \\ Matheus Dias Cordeiro'; Claudia Bezerra da Silva'; Maylin Gonzalez Navarrete²; Eugênio Roque²; \\ Adivaldo Henrique da Fonseca1* (1) \\ 'Departamento de Epidemiologia e Saúde Pública, Instituto de Veterinária, Universidade Federal Rural do Rio de Janeiro - UFRRJ, \\ Seropédica, RJ, Brasil \\ ${ }^{2}$ Departamento de Prevención, Facultad de Medicina Veterinaria, Universidad Agraria de La Habana - UNAH, Mayabeque, Cuba
}

How to cite: Cordeiro MD, Silva CB, Gonzalez Navarrete M, Roque E, Fonseca AH. First serological detection of Borrelia spp. in dogs in western Cuba. Braz J Vet Parasito/ 2020; 29(4): e014020. https://doi.org/10.1590/S1984-29612020104

\begin{abstract}
This study aimed to verify the presence of IgG antibodies against Borrelia burgdorferi sensu lato (s.l) in domestic dogs in western Cuba. Serum samples were analyzed by indirect enzyme-linked immunosorbent assay (ELISA), using crude antigens of a B. burgdorferi strain of North American origin. To verify the presence of Borrelia spp., deoxyribonucleic acid (DNA) extracted from individual blood samples was analyzed by nested-PCR, with markers targeted for amplification of portions of the flagellin B gene (flaB) present in Borrelia spirochetes. Ticks were also collected through inspection of the animals. Sera from 93 of 176 (52.84\%) dogs were reactive to the indirect ELISA. Geographic prevalence varied from 54.35\% (25/46) in Boyeros, 44.44\% (20/45) in Cotorro, 66.67\% (22/33) in Habana del Este, and 50\% (26/52) in San José de las Lajas. There was no statistical difference between these tested variables. No blood samples analyzed were positive for the Borrelia flaB gene.
\end{abstract}

Keywords: Domestic dogs, borreliosis, diagnosis, Cuba.

\section{Resumo}

Este estudo teve como objetivo confirmar a presença de anticorpos IgG contra Borrelia burgdorferi sensu lato (s.l) em cães na região oeste de Cuba. As amostras de soro foram analisadas por ensaio de imunoabsorção enzimática (ELISA) indireto, usando-se antígenos brutos de uma cepa de B. burgdorferi de origem norte-americana. Para confirmar a presença de Borrelia spp., o ácido desoxirribonucleico (DNA), extraído de amostras individuais de sangue, foi analisado por PCR, utilizando-se marcadores direcionados para a amplificação de porções do gene da flagelina B (flaB) presente nas espiroquetas de Borrelia. Os carrapatos também foram coletados através da inspeção dos animais. Os soros de 93 de 176 (52,84\%) cães foram reativos ao ELISA indireto. A prevalência geográfica variou de 54,35\% (25/46) em Boyeros, 44,44\% (20/45) em Cotorro, 66,67\% (22/33) em Habana del Este e $50 \%$ (26/52) em San José de las Lajas. Não houve diferença estatística entre essas variáveis testadas. Nenhuma amostra de sangue analisada foi positiva para o gene Borrelia flaB.

Palavras-chave: Cães, borrelioses, diagnóstico sorológico, Cuba. 


\section{Introduction}

Pathogenic spirochetes of the Borrelia genus are maintained in nature in a cycle that includes arthropod vectors, mammals, birds, and reptiles. Phylogenetic studies indicate the existence of three disease groups within Borrelia: (1) Lyme borrelioses (LB)/Lyme disease, transmitted by Ixodidae; (2) recurrent fever, transmitted by Argasidae and Ixodidae (one exception, Borrelia recurrentis, is transmitted by lice); and (3) reptile-associated Borrelia (BAR), transmitted by Ixodidae.

The first report of borreliosis in dogs was described in Lyme disease endemic area in the U.S. (Dewage et al., 2019). The occurrence of Borrelia burgdorferi sensu lato (s.l.) is dependent on the occurrence of ticks of the genus Ixodes (Eisen \& Eisen, 2018). In recent decades, there has been an increase in the geographical range and incidence of I. scapularis, coinciding with an increase in the incidence of tick-borne diseases, particularly LB in the northeastern U.S. (Eisen \& Eisen, 2018). According to Bowman et al. (2009), county incidence of LB is substantially lower in the Southern U.S.: B. burgdorferi-specific antibodies were reported in less than $1 \%$ of dogs from the South. In other areas, dogs are considered important reservoirs, and spirochetes can be isolated from clinically healthy animals (Dewage et al., 2019).

In Cuba, González et al. (2018), in a retrospective study on BL's occurrence in humans, found that the available knowledge refers to clinical and epidemiological aspects, compatible with BL. Similar observations were made in Brazil (Lopes et al., 2017).

Besides Borreliosis, other Tick-Borne Pathogens (TBPs) were investigated in Cuba. Antibodies to Anaplasma phagocytophilum, Ehrlichia chaffeensis and Babesia microti were detected in $7.2 \%, 3.6 \%$, and $11.5 \%$ of studied human serum samples, respectively (Rodríguez et al., 2018) and Silva et al. (2016) described the first evidence of the presence of Anaplasma platys in dogs and $R$. sanguineus ticks, demonstrating hemoparasites circulating in the island.

Also, Obregón Alvarez et al. (2020) published a review that covers research results including ecophysiology of ticks, the epidemiology of TBPs in Cuba,

The aim of the present study was to evaluate the occurrence of homologous IgG antibodies against $B$. burgdorferi (s.l) in domesticated dogs, as well as the possible detection of Borrelia spp. in four municipalities in western Cuba.

\section{Material and Methods}

A total of 176 blood samples were collected from dogs in the municipalities of Habana del Este, Boyeros, and Cotorro in the province of La Habana and San Jose de las Lajas in the province of Mayabeque between October and December 2013.

Blood samples were obtained from the cephalic vein and the blood was transferred to sterile containers with and without anticoagulant (EDTA). Subsequently, the blood without EDTA was centrifuged and the sera obtained were stored in polypropylene vials. The samples with and without EDTA were kept at $-20^{\circ} \mathrm{C}$ until analysis. The ticks collected were properly identified according to a taxonomic key described by Barros-Battesti et al. $(2006,2009)$. The procedures for collecting and identifying ticks used in this study, in addition to extracting DNA from these specimens, were previously published by Navarrete et al. (2016).

The serum was tested for IgG against the crude antigen of B. burgdorferi strain G39/40 using an indirect ELISA, adapted from Joppert et al. (2001) and using the methodology proposed by Voller et al. (1976). Microwell medium binding plates (NUNC $®$ Surface Maxisorp) were coated with $100 \mu \mathrm{L} /$ well of $B$. burgdorferi antigen at a concentration of $15 \mathrm{\mu g} / \mathrm{ml}$ solubilized in $0.05 \mathrm{M}$ sodium carbonate/bicarbonate buffer $(\mathrm{pH} 9.6)$ and incubated at $4{ }^{\circ} \mathrm{C}$ overnight. After incubation, the plates were washed three times with PBS (pH 7.4) containing $0.05 \%$ Tween-20 (PBST). The plates were blocked for 90 min at $37{ }^{\circ} \mathrm{C}$ with 200 microliters of $6 \%$ skim milk powder solution in PBST and washed 3 times in PBST. Control and test sera were diluted 1: 800 in 5\% milk/PBST and $100 \mu \mathrm{L}$ was added to the appropriate microwells. The plates were incubated for $90 \mathrm{~min}$ at $37^{\circ} \mathrm{C}$ and washed three times in PBST. Then $100 \mu \mathrm{L}$ of alkaline phosphatase anti-dog IgG (integral) (SIGMA®) diluted 1: 10,000 in 5\% Milk/PBST was added to each well and the plates were incubated for $90 \mathrm{~min}$ at $37^{\circ} \mathrm{C}$. The plates were washed three times in PBST, and $100 \mu \mathrm{L}(1 \mathrm{mg} / \mathrm{mL})$ of p-nitrophenyl phosphate substrate (pNPP-SIGMA®) solubilized in diethanolamine buffer $(\mathrm{pH} 9.8)$ was added to each well and incubated for $25 \mathrm{~min}$ at room temperature. The optical density (OD) of each plate was measured at $405 \mathrm{~nm}$ using a microplate reader. Twelve known negative samples from animals from the municipality of Seropédica, Brazil and a positive control sample from an animal with hyper immunity for Borrelia (vaccinated with crude $B$. burgdorferi antigen) were used. 
The cutoff point was calculated using the negative controls as in Frey et al. (1998). To correct the effect of the OD of each plate, the value of the cut sheets was transformed to 100 , so the optical density index was calculated based on the formula ODx100/cutoff. The relationship between variables likely associated such as race, sex, age, and street access were performed using the chi-square test with a 95\% confidence interval. Statistical analyses were performed using BioEstat 5.3.

The DNA were extracted using the Wizard ${ }^{\circledR}$ Genomic DNA Purification kit (Promega) per manufacturer recommendations. Molecular analysis to detect Borrelia spp. was performed by the nested-PCR technique on DNA from blood samples of antibody-positive animals.

The DNA extracted from blood samples was analyzed individually via nested-PCR, with markers targeted for amplification of portions of the flagellin $\mathrm{B}(\mathrm{flaB})$ gene present in spirochetes of the Borrelia genus. For the first reaction, we used the FlaLL (5'-ACATATTCAGATGCAGACAGAGGT-3') and FlaRL (5'-GCAATCATAGCCATTGCAGATTGT-3') primers and for the second reaction, we used the FlaLS (5'-AACAGCTGAAGAGCTTGGAATG-3') and FlaRS (5'-CTTTGATCACTTATCATTCTAATAGC-3') primers (Ataliba et al., 2007). The PCR reaction mixtures contained $1.0 \mathrm{U}$ of GoTaq ${ }^{\circledR}$ DNA Polymerase (Promega ${ }^{\circledR}$, Brazil), 1x Green GoTaq ${ }^{\circledR}$ reaction buffer, $1.5 \mathrm{mM} \mathrm{MgCl}{ }_{2}, 0.2 \mathrm{mM}$ dNTPs, 1.25 pmoles of each primer and $2.5 \mu \mathrm{L}$ of DNA template. Samples were initially heated to $95^{\circ} \mathrm{C}$ for 5 min to denature the template and activate the polymerase, followed by 35 cycles of denaturation at $95^{\circ} \mathrm{C}$ for 60 seconds, annealing at $55^{\circ} \mathrm{C}$ for 60 seconds, and extension at $72{ }^{\circ} \mathrm{C}$ for 60 seconds, followed by a final extension at $72{ }^{\circ} \mathrm{C}$ for five minutes. The obtained products were analyzed by gel electrophoresis (1.5\% agarose). For each reaction, one positive (DNA of $B$. anserina strain $\mathrm{AL}$ ) and two negative controls (water) were included in the reaction.

\section{Results and Discussion}

A total of 176 blood samples were collected from dogs in the municipalities of Habana del Este $(n=33)$, Boyeros $(n=46)$, Cotorro $(n=45)$ in the province of La Habana and San Jose de las Lajas $(n=52)$ from the province of Mayabeque. The animals sampled appeared healthy and were different ages, sexes, and breeds.

Of the 176 tested sera, a total of $93(52.84 \%)$ were reactive to the indirect ELISA. By geographic location, antibodies were detected in 54.35\% (25/46) of the animals in Boyeros, 44.44\% (20/45) in Cotorro, 66.67\% (22/33) in Habana del Este, and 50\% (26/52) in San José de las Lajas. The optical density indexes obtained in each city are shown in Figure 1. The prevalence found according to breed, sex, age, and street access is shown in Table 1. There were no statistically significant differences between the tested variables. A total of 158 ticks ( 84 males, 48 females, 24 nymphs, 2 larvae) were collected from Habana del Este, Boyeros with 153 (95 males, 44 females, 14 nymphs) specimens, San José de las Lajas with 73 (48 males, 16 females, 9 nymphs) and Cotorro with 47 ( 23 males, 8 females, 16 nymphs), all identified ticks belonged to the Rhipicepahlus sanguineus s. I. species (Navarrete et al., 2016). In no blood and tick DNA samples tested by nested PCR was the specific flaB gene of Borrelia found.

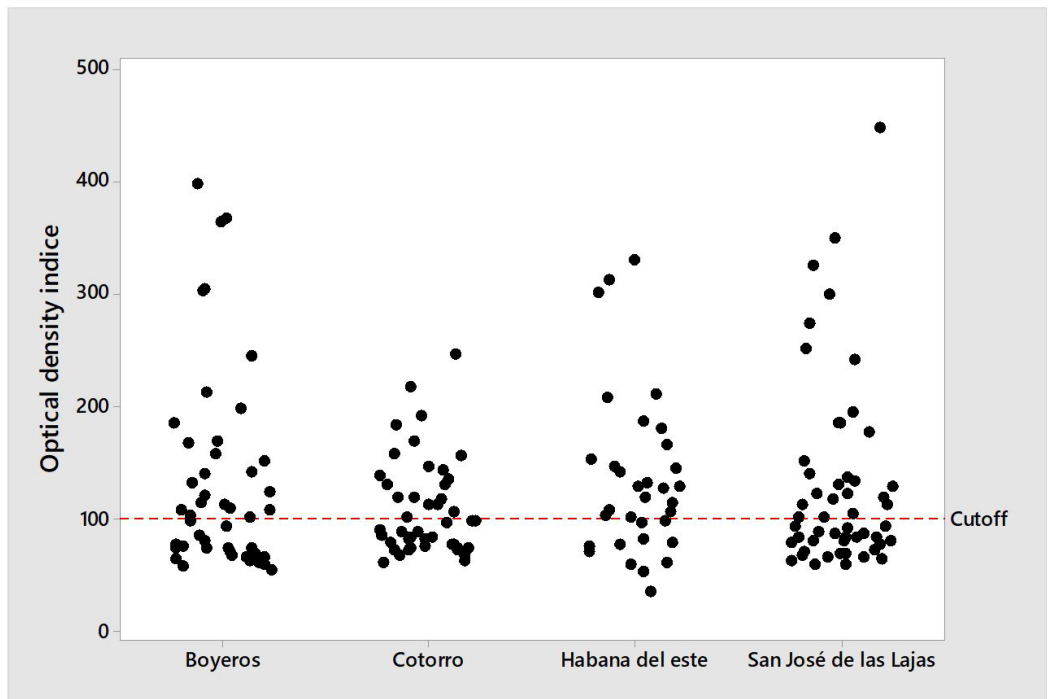

Figure 1. Distribution of optical densities of animals in relation to the cutoff (DOx100/cutoff) obtained from the indirect ELISA test for Borrelia burgdorferi in dogs sera from the municipalities of Boyero, San José de las Lajas, Habana del Este and Cotorro, Western region of Cuba. 
Table 1. Analysis of the intrinsic characteristics of dogs tested for Borrelia burgdorferi, diagnosed through In-house ELISA in the Western region of Cuba in 2013.

\begin{tabular}{|c|c|c|c|c|c|}
\hline \multirow{2}{*}{ Variables } & \multirow{2}{*}{$\mathbf{N}$} & \multirow{2}{*}{$\mathrm{P}(\%)$} & \multicolumn{2}{|c|}{ Bivariate } & \multirow{2}{*}{ PR } \\
\hline & & & $\chi^{2}$ & p-value & \\
\hline \multicolumn{6}{|c|}{ Access to the street } \\
\hline No & 81 & 0.23 & 1.399 & 0.3021 & 0.84 \\
\hline Yes & 95 & 0.30 & & & \\
\hline \multicolumn{6}{|l|}{ Breed } \\
\hline Crossbreed & 93 & 0.28 & 0.469 & 0.5940 & 0.91 \\
\hline Pure & 83 & 0.25 & & & \\
\hline \multicolumn{6}{|l|}{ Gender } \\
\hline Females & 92 & 0.26 & 1.570 & 0.2760 & 0.84 \\
\hline Males & 84 & 0.27 & & & \\
\hline \multicolumn{6}{|l|}{ Age } \\
\hline$<5$ years & 91 & 0.27 & 0.444 & 0.6068 & 0.91 \\
\hline$\geq 5$ years & 85 & 0.26 & & & \\
\hline
\end{tabular}

$\mathrm{N}=$ number of animals; $\mathrm{P}=$ prevalence; $\chi 2=$ Chi-square value; $\mathrm{PR}=$ prevalence ratio.

The prevalence of $52.84 \%$ by indirect ELISA for Borrelia spp. found in this study is consistent with epidemiological studies in dogs in an area endemic for LB in the U.S. (Bowman et al., 2009), and the serological prevalence determined by OD is consistent with studies carried out in South America, specifically, in Brazil (Cordeiro et al., 2012).

Despite the epidemiological importance, there are no studies reporting the presence and the prevalence of Borrelia spp. in the blood of antibody-positive animals. The same results were found by Socoloski et al. (2018) in Brazil and it can be explained by the low spirochetemia that occurs in chronic cases. Molecular diagnosis can be a limiting technique as it is most accurate when used during the acute phase of infection (Mantovani et al., 2012).

In South America, spirochetes of Borrelia genus are suspected of causing disease in humans (Lopes et al., 2017). However, the lack of a Borrelia isolate does not confirm the existence of real cases of LB in South America. Similar results have been found in Cuba (Rodríguez et al., 2004).

Sokoloski et al. (2018) have suggested that the tick species Rhipicephalus microplus, Rhipicephalus sanguineus, and, primarily, Amblyomma sculptum are involved in the transmission of this agent in South America, however, no study has substantiated this hypothesis. In Southern Hemisphere there are only culture isolation of borreliae from the Borrelia recurrentis group (Muñoz-Leal et al., 2018), and the Borrelia theileri isolate from R. microplus (Cordeiro et al., 2018) as the only one found in ticks of domestic animals may suggest cross-reaction in serological data domestic animals (Cordeiro et al., 2012) and humans (Yoshinari et al., 2003). Four Borrelia spp. fla haplotypes findings from the $B$. burgdorferi s.l. group were carried out in this part of the continent, but the vector species were ticks of the genus Ixodes with no reports of infestation in humans (Carvalho et al., 2020). The four fla haplotypes were registered in GenBank accession numbers MK160129, MK160130, MK160131, and MK160132 by Carvalho et al., (2020).

This is the first serological detection of Borrelia spp. in animals residing in Cuba as to date. In Cuba studies have focused on human beings (Rodríguez et al., 2003, 2004, 2012). According to Rodríguez et al. (2012), the serological data obtained indicate that the LB agent circulates at a relatively low prevalence in the Cuban population, emphasizing the epidemiological alert to the national health authorities.

Among the 32 tick species reported in Cuba (23 Argasidae and nine Ixodidae), only one species belong to the genus Ixodes, Ixodes capromydis, a parasitizes of the genus Capromydis rodents, but it has limited distribution and there has been no description of it parasitizing in humans (Barros-Battesti et al., 2009). In contrast, the Amblyomma cajennense tick (A. cajennense complex) has a wide distribution in Cuban territory and low host specificity. Other species of Ixodidae found in Cuba include Amblyomma albopictum, Amblyomma dissimile, Amblyomma quadricavum, 
Amblyomma torrei, Dermacentor nitens, $R$. microplus, and $R$. sanguineus, the latter is a typical species infecting dogs (Barros-Battesti et al., 2009; Silva et al., 2016) and it was the only species found in the animals tested in this study.

The presence of seropositive dogs indicates the presence of spirochetes of the genus Borrelia on the island of Cuba. Our results may be used by local health authorities to further improve investigations aimed at clarifying potential human LB cases and the participation of dogs as reservoirs for these agents.

\section{Acknowledgements}

We would like to express our gratitude to the Conselho Nacional de Desenvolvimento Científico e Tecnológico - CNPq (A.H.F. 312169/2017-5), Coordenação de Apoio ao Aperfeiçoamento de Pessoal de Nível Superior - CAPES and Fundação de Apoio à Pesquisa no Estado do Rio de Janeiro (A.H.F. E-26/202.813/2017).

\section{References}

Ataliba AC, Resende JS, Yoshinari N, Labruna MB. Isolation and molecular characterization of a Brazilian strain of Borrelia anserina the agent of fowl spirochaetosis. Res Vet Sci 2007; 83(2): 145-149. http://dx.doi.org/10.1016/j.rvsc.2006.11.014. PMid:17222877.

Barros-Battesti DM, Arzua M, Bechara GH. Carrapatos de importância médico-veterinária da região neotropical: um guia ilustrado para identificação de espécies. 1. ed. São Paulo: Vox/ICTTD-3/Butantan; 2006.

Barros-Battesti DM, Hernández MR, Famadas KM, Onofrio VC, Beati L, Guglielmone AA. The ixodid ticks (Acari: Ixodidae) of Cuba. Syst Appl Acarol 2009; 142(2): 101-128. http://dx.doi.org/10.11158/saa.14.2.3.

Bowman D, Little SE, Lorentzen L, Shields J, Sullivan MP, Carlin EP. Prevalence and geographic distribution of Dirofilaria immitis, Borrelia burgdorferi, Ehrlichia canis, and Anaplasma phagocytophilum in dogs in the United States: results of a national clinicbased serologic survey. Vet Parasitol 2009; 160(1-2): 138-148. http://dx.doi.org/10.1016/j.vetpar.2008.10.093. PMid:19150176.

Carvalho LA, Maya L, Armua-Fernandez MT, Félix ML, Bazzano V, Barbieri AM, et al. Borrelia burgdorferi sensu lato infecting Ixodes auritulus ticks in Uruguay. Exp Appl Acarol 2020; 80(1): 109-125. http://dx.doi.org/10.1007/s10493-019-00435-8. PMid:31807933.

Cordeiro MD, Bahia M, Magalhães-Matos PC, Cepeda MB, Guterres A, Fonseca AH. Morphological, molecular and phylogenetic characterization of Borrelia theileri in Rhipicephalus microplus. Rev Bras Parasitol Vet 2018; 27(4): 555-561. http://dx.doi.org/10.1590/ s1984-296120180083. PMid:30517424.

Cordeiro MD, Meireles GS, Silva JB, Souza MMS, Fonseca AH. Soroprevalência para Borrelia spp. em cães no município de Seropédica, estado do Rio de Janeiro. Rev Bras Med Vet 2012; 34(3): 251-256.

Dewage BG, Little S, Payton M, Beall M, BraffJ, Szlosek D, et al. Trends in canine seroprevalence to Borrelia burgdorferi and Anaplasma spp. in the eastern USA, 2010-2017. Parasit Vectors 2019; 12(1): 476. http://dx.doi.org/10.1186/s13071-019-3735-x. PMid:31610803.

Eisen RJ, Eisen L. The blacklegged tick, Ixodes scapularis: an increasing public health concern. Trends Parasitol 2018; 34(4): 295309. http://dx.doi.org/10.1016/j.pt.2017.12.006. PMid:29336985.

Frey A, Di Canzio J, Zurakowski D. A statistically defined endpoint titer determination method for immunoassays. J Immunol Methods 1998; 221(1-2): 35-41. http://dx.doi.org/10.1016/S0022-1759(98)00170-7. PMid:9894896.

González IR, Noda Ramos AA, Pérez EE, Barrera MER, Hernández TMI, Lienhard R. Acerca de la enfermedad de Lyme en Cuba y su conocimiento en personal médico. Rev Cuba Salud Pública [online]. 2018; 44(1): 3-13 [cited 2020 June 12]. Available from: https://pesquisa.bvsalud.org/portal/resource/pt/biblio-1042969

Joppert AM, Hagiwara MK, Yoshinari NH. Borrelia burgdorferi antibodies in dogs from Cotia county, São Paulo State, Brazil. Rev Inst Med Trop São Paulo 2001; 43(5): 251-255. http://dx.doi.org/10.1590/S0036-46652001000500003. PMid:11696846.

Lopes FA, Rezende J, Silva DBS, Alves FCG, Oliveira CE, Costa IP. Evidência molecular de Borrelia burgdorferi sensu lato em pacientes no centro-oeste Brasileiro. Rev Bras Reumatol 2017; 57(6): 641-645. http://dx.doi.org/10.1016/j.rbr.2017.04.001.

Mantovani E, Marangoni RG, Gauditano G, Bonoldi VLN, Yoshinari NH. Amplification of the flgE gene provides evidence for the existence of a Brazilian borreliosis. Rev Inst Med Trop São Paulo 2012; 54(3): 153-157. http://dx.doi.org/10.1590/S003646652012000300007. PMid:22634887.

Muñoz-Leal S, Faccini-Martínez ÁA, Costa FB, Marcili A, Mesquita ETKC, Marques EPJr, et al. Isolation and molecular characterization of a relapsing fever Borrelia recovered from Ornithodoros rudis in Brazil. Ticks Tick Borne Dis 2018; 9(4): 864-871. http://dx.doi. org/10.1016/j.ttbdis.2018.03.008. PMid:29571703.

Navarrete MG, Cordeiro MD, Silva CB, Pires MSA, Ribeiro CDU, Cabezas Cruz A, et al. Molecular detection of Ehrlichia canis and Babesia canis vogeli in Rhipicephalus sanguineus sensu lato ticks from Cuba. Rev Bras Med Vet 2016; 38(Suppl. 3): 63-67. 
Obregón Alvarez D, Corona-González B, Rodríguez-Mallón A, Rodríguez Gonzalez I, Alfonso P, Noda Ramos AA, et a. Ticks and tick-borne diseases in Cuba, half a century of scientific research. Pathogens 2020; 9(8): 616. http://dx.doi.org/10.3390/ pathogens9080616. PMid:32731487.

Rodríguez I, Fernández C, Cinco M, Pedroso R, Fuentes O. Do antiborrelial antibodies suggest Lyme disease in Cuba? Emerg Infect Dis 2004; 10(9): 1698-1700. http://dx.doi.org/10.3201/eid1009.031048. PMid:15503414.

Rodríguez I, Fernández C, Sánchez L, Martínez B, Siegrist HH, Lienhard R. Prevalence of antibodies to Borrelia burgdorferi sensu stricto in humans from a Cuban village. Braz J Infect Dis 2012; 16(1): 82-85. http://dx.doi.org/10.1016/S1413-8670(12)70280-5. PMid:22358362.

Rodríguez I, Noda AA, Fuentes O, Lienhard R, Gern L. Evidences about human tick-borne infections in Cuba. Acta Biom Scient 2018; 3(5): 164-165. http://dx.doi.org/10.29413/ABS.2018-3.5.25.

Rodríguez I, Pedroso R, Fernández C, Cinco M, Fuentes O. Lyme disease in Cuba? Report of possible cases. Rev Cubana Med Trop 2003; 55(1): 41-43. PMid:15849952.

Silva CB, Santos HA, Navarrete MG, Ribeiro CCDU, Gonzalez BC, Zaldivar MF, et al. Molecular detection and characterization of Anaplasma platys in dogs and ticks in Cuba. Ticks Tick Borne Dis 2016; 7(5): 938-944. http://dx.doi.org/10.1016/j.ttbdis.2016.04.012. PMid:27132516.

Socoloski SNG, Castro BG, Cordeiro MD, Fonseca AH, Cepeda MB, Nicolino RR, et al. Epidemiological investigation of Borrelia burgdorferi in horses in the municipality of Sinop-MT, Brazil. Trop Anim Health Prod 2018; 50(4): 831-836. http://dx.doi.org/10.1007/ s11250-017-1504-4. PMid:29388162.

Voller A, Bidwell D, Bartlett A. Enzyme immunoassays in diagnostic medicine: theory and practice. Bull World Health Organ 1976; 53(1): 55-65. PMid:1085667.

Yoshinari NH, Abrão MG, Bonoldi VLN, Soares CO, Madruga CR, Scofield A, et al. Coexistence of antibodies to tick-borne agents of babesiosis and Lyme borreliosis in patients from Cotia County, State of Sao Paulo, Brazil. Mem Inst Oswaldo Cruz 2003; 98(3): 311-318. http://dx.doi.org/10.1590/S0074-02762003000300004. PMid:12886408. 